\author{
Journal of Applied Sports Science \\ December 2018, Volume 8, No. 1 \\ www.jass.alexu.edu.eg
}

\title{
Governance Determinants and Relationship with Competitive Advantage in Sports Organization
}

\author{
Hassan Ahmed Elshafei ${ }^{1}$, Nadia Lotfy Abdel Fattah ${ }^{2}$ \\ ${ }^{1}$ Professor of Sports Administration of sports management, Faculty of physical Education for Girls, Alexandria University \\ ${ }^{2}$ Assistant Professor of sports management, Faculty of physical Education for Girls, Alexandria University
}

\begin{abstract}
Governance is an important mechanism of dealing with administrative corruption through some mechanisms including transparency, declaring and preparing financial and administrative information according to accounting norms as well as enhancing role of control, editing and independence of work system. The objective of the research is to find out the relationship between governance standards (internal determinants - external determinants) and the exclusion of competitive advantage (cost - quality - flexibility - delivery - creativity). In the sports clubs, the descriptive removed approach was used to suit the nature of the research. - the general manager of sports activity, the directors of sports activities and specialists for various sports activities ", and a sample of beneficiaries. The researchers used the questionnaire form as a means of collecting data. The most important recommendations are the importance of changing the current management style in most sports clubs, the cornerstones of the success of sports clubs and the achievement of competitive advantage.
\end{abstract}

\section{Introduction}

G overnance need emerged in many advanced and emerging economies within the few late decades as a result of economic collapse and financial crises to which may countries exposed like countries of East Asia and Latin America as well as what was witnessed lately by the U.S economy of financial.(39)

Governance is one of the most important requirements and exigencies whose application became essential in the near past, to secure work organization in private and public sector organizations at local, (40)

Clap report that it is the frame in which organizations practice their existence and through which it focuses on the relationship between employees, board's members, shareholders, stakeholders and governmental organizations composers. (11:5)

If defines governance as: "The system through which companies are managed and their businesses are controlled". (1:86)

Also aced defines it as: "Some relationships between company's administrators, board and shareholders". (12:79)
Some define as: "The sum of game rules used for the company's administration from inside and for making the board supervise to protect the shareholders' interests and financial results, in other words; governance means system, systems control. (32:46)

Accordingly the researchers agree with the opinion of Mohamed Hassan Youssef (2007)(27) that governance concept includes:

Organizing the relationship between board, investors, shareholders and other stakeholders.

Accordingly, Tirs Odisho (2011) mentions that there is no one united definition for sports governance a there are many definitions in sports organization, however; it can be defined as the system through which the organization and its departments can be directed . (38:10)

Total objectives to be achieved as a result of applying governance are as follows:

Achieving transparency and justice and entitling the organization's management to question the competent authorities

Protecting the public property taking into account interests of dealers with different state organizations. (10:119) 
Norms of OECD for companies' governance:

Governance was applied according to 6 norms reached by OECD in (2004) represented as follows:

Securing bases of the companies effective governance frame.

Shareholding rights and main property functions. (19:26)

It is agreed upon that good companies governance depends on availability and quality of 2 determinants groups; external and internal groups

\section{First External Determinants:}

Indicate the general climate of the state investment represented in laws organizing economic development such as laws of capital market, competence organization, antitrust and bankruptcy, financial sector efficiency (banks and capital market) in availing finance. (18:87)

\section{Second Internal Determinants}

Indicate rules and bases identifying how to take decisions and distribute authorities in the company to general assembly, boards and executive managers whose availability from one side and application from the other side may reduce conflict of these three parties' interests. (21:92)

Competitive advantage is factor of the organization's excellence achieved in case of adopting a certain competitive strategy as the competitive advantage emerges upon the organization reaches new methods more effectives then used by competitors. (28:39)

Also Marawan Mohamed Naguib (2011) and Moustafa Mahmoud Abo Bakr (2005) agree upon that the competitive advantage is not only clear in responding to challenges faced by businesses organizations. but as an integrated organization for taking decisions related to competitive advantage outperforming their competitors due to its importance in providing the organization with control over beneficiaries and meeting their rapid variegated needs (24:67) (30:18)

Accordingly any organization shall focus on its competitive position whether to protect, maintain, develop or support the same which requires acquiring a variegated competitive advantage, (34:31)

Also Mohy Eldin Elkotb (2012) states that organizations success in future will depend on finding new models of competitive advantage, as long as old models became widely known and available and achieving a competitive advantage creates the value for organization and its clients. $(25: 20)$
Ali Elselmy (2011) states that organization, through the competitive advantage tries to reach some objectives including creating new marketing opportunities. (4:104)

According to what was declared by Saudi Sports Authority about sports clubs governance regulation aiming at having norms and rules organizing Saudi Sports clubs administration in addition to applying the best governance practice for sports clubs (42)

According to the former results and recommendations of some previous studies such as (Jinarat \& Quang, 2003) (22) there is a positive relationship between concepts of good organizational governance and good governance at the functional level, study of (Ho, 2005) (16) the more obligation of companies studied by governance is stronger, the more they enjoy a greater competitiveness, study of Manwer Hadad (2008) (31) stated that companies governance is the effective and outlet solution to guarantee stakeholders' rights specially investors.

Study of Kabaha Abdel Rahman Adnan (2008) (2) of the most striking results reached by the study was a directing correlation between organizational governance efficiency from one side and return of property right, return of investment, Badr Ayed El Eitibi study (2013) (6) of the most important results is that fraud whether spontaneous, strategic or organizational is nothing but resultants of bad behavior patterns aiming at directing competition .Fadl Mohamed Moaid (2015) (13) of its most importance results is low quality of accounting declaration in general Iraqi companies, Study of Riham Amin Hamza (2015) (36) of the most important results is that the idea of applying governance in sports clubs is not clear and applying governance to clubs is not common.

Also some studies like study of Mohamed Magdy Sayed (2009) (29) that recommended the importance of applying governance to sports organization like sports clubs. the administration deviated behavior. Rashed Ibrahim El Motwae Elneimi (2015) (35) there should be future studies to know change of level of applying governance in sports organizations in United Arab Emirates, Barbris Sheriff (17) that recommended the importance of focusing on moral dimension through holding training courses, specialized seminars.

Study of Mohamed Elsaleh Froom (2016) (26) recommended the importance of encouraging such organizations to apply organizations governance system and urging them to issue a manual of this system.

In addition to looking into manual of companies governance rules and norms in Egypt issued by ministry of 
health in February (2016), attachment number (1) to know bases and determinants of governance in sports clubs.

According to the above results and recommendations of some studies and in addition. As the importance of the role played by governance to develop competitive performance efficiency under environment variables.

\section{Research Objectives}

1- Identifying governance determinants in sports clubs (internal determinants - external determinants)

2- Identifying competitive advantage dimensions in sports clubs (cost - quality - flexibility - delivery - creation)

3- Identifying the relationship between governance determinants and competitive advantages dimensions in sports clubs.

\section{Research question}

Is there any correlation between governance determinants (internal determinants - external determinants) and competitive advantage (cost - quality - flexibility delivery - creation) in sports clubs?

Research Procedures:

Descriptive method was used as suitable for the research nature

\section{Research sample}

And Alemtemthleean in: sports clubs by (8) clubs "Ahly Club - Zamalek - Al Jazira Club - Sun Club - Smouha Sporting Club - Alexandria Sporting Club - Guard Club Alhdod- Olympic Club.

Table (1)

Numerical description of the study sample distributed to pilot and main studies

\begin{tabular}{|c|c|c|c|c|c|c|c|c|}
\hline \multirow{2}{*}{ Research Groups } & \multicolumn{2}{|c|}{ Total sample } & \multicolumn{2}{|c|}{ Pilot sample } & \multicolumn{2}{|c|}{ Removed sample } & \multicolumn{2}{|c|}{ Main sample } \\
\hline & Number & $\%$ & Number & $\%$ & Number & $\%$ & Number & $\%$ \\
\hline Clubs board's members & 72 & 25.09 & 5 & 6.94 & 11 & 15.28 & 56 & 77.778 \\
\hline $\begin{array}{l}\text { Employees of sports } \\
\text { activity department in } \\
\text { sports clubs }\end{array}$ & 120 & 41.81 & 10 & 8.33 & 12 & 10.00 & 98 & 81.667 \\
\hline Beneficiaries & 95 & 33.10 & 8 & 8.42 & 7 & 7.37 & 80 & 84.211 \\
\hline Total & 287 & 100 & 23 & 8.01 & 30 & 10.45 & 234 & 81.533 \\
\hline
\end{tabular}

The dimensions of data: The researchers used an average agreement percentage between (48.29: 89.74 questionnaire form to collect data $\%)$

\section{Questionnaire Form Scientific Coefficient:}

\section{First: Form Validity:}

To reach form validity, the researchers depended on:

\section{Internal Consistency Validity}

Table number (2) internal consistency coefficient (coefficient of the phrase correlation with the grand total of its dimension)

\section{"Result and Discussion"}

From table number (5), it is clear that $\mathrm{K} 2$ values are less than the tabular value at significance level $(0.05)$ to prove non statistical significant difference in responses of opinions of the total research sample group on the first factor phrases related to governance in sports clubs (external determinants of sports clubs governance) except for phrases number (4) (9) (10), as K2 values reached $(* 12.41),(* 10.58),(* 8.69)$ a value higher than the tabular one, accordingly it is statistically significant, the total research sample opinion of all the first factor phrases has
Phrase number (1) took the second order between the first dimension phrases stipulating "executing laws and rules including good sports clubs administration and their relationship to other sports competent and non competent authorities" as the total agreement percentage reached $(88.89 \%)$

Accordingly Ahmed Mounir El Nagar (2007) (3) indicates that external determinants refer to investment general climate in the state including factors general laws regulating economic activity.

While the phrase (8/2) related to "adopting declaration policy, freedom of expression and questioning in sports clubs", obtained the latest agreement percentage between the research sample groups opinions which reached. $(48.29 \%)$

Accordingly Hamada Abdelal Tarek (2007) (14) states that good declaration systems encouraging real transparency is a main characteristic of methods of following organizations depending on market forces. 
By looking into phrase number (4) ", we will find an agreement of board's members and employees of sports activity department at high agreement percentage (62.50 $\%)(88.78 \%)$ respectively while the third group agreement, beneficiaries was lower as reached (48.75\%) as both researchers agree the third opinion, beneficiaries, as they are more familiar with the same.

According to these results, results of study of (Shuli 2011) (37) confirms that declaration and transparency are main factors of organizations governance having an effective role in controlling organizations departments to prevent from misusing power and urging to protect rights of shareholders .

From Table number (6), it is clear that values of( K2 )are less than tabular value at significant level (0.05) which means no statistical significant difference in responses of the whole research sample groups opinions to the first factor phrases related to "governance determinants in sports clubs" (internal determinants of sports clubs governance), except for phrases (12), (17), (19), (20), (21), 922, (23), (24), (30) which were statistically significant as $\mathrm{K} 2$ value bigger than the tabular one which ranged between $(* 6.15: * 18.01)$ a values greater than the tabular value accordingly they are statistically significant, as the total research sample opinions of all phrases of the second dimension of the first factor had an average agreement percentage between (48.29: $94.87 \%)$.

The phrase (18/2) indicating determination of administration and financial corruption causes in sports organizations has a highest percentage of agreement between the research groups opinion $(94.87 \%)$.

Accordingly study of Barbris Sheriff (2015) (8) recommended the importance of anti corruption at the local level and enhancing their partnership with international police in sports field, in addition to creating courts for sports anti corruption at the local level.

As the phrase number (14) of availing transparency in financial and non financial statement issued from sports organizations had the least agreement percentage between the research sample groups opinion reached $(48.29 \%)$

Also study of Barbris Sheriff (2015) (8) recommended questioning and transparency of decision making and financial operations in sports organizations and deploying among all parties related to, in addition to enhancing transparency .

Phrase (12) related to informing employees of dimensions and risks of committing any illegal act in work, had a percentage of agreement of all board's members and employees of sports activity department ranged between (76.53 : $94.64 \%)$ while percentage of the third group agreement was less and reached $(48.75 \%)$.

These results agree with what was mentioned in October (2011) (27) as FIFA designed a road map to achieve Orthodox rule as a first step as four work groups were established for reviewing the main system and reconsidering moral and transparency committee and loyalty to football, also the executive committee established in December (2011) a new committee independent governance (CIG), FIFA looked into many repairs and many of the same affect its departments financially.

While phrase number (30) indicating "applying financial and moral incentives by the supreme administration to achieve work perfectly" obtained the agreement of board's members and beneficiaries with agreement percentage between (83.75: $92.86 \%$ ) as employees of sports activity disagreed with them at percentage $(46.94 \%)$

These results agree with study of El Naser and El Neimi (2013) (33) that governance is a system to enhance control and administration and a general frame to identify responsibilities and duties in economic unit in conformity with developing performance and availing financial statements free from fraud and errors in conformity with investment decisions and make the unit clear for all investors.

It is clear from table number (13) that values of $\mathrm{K} 2$ are less than tabular value at significant level $(0.05)$ to prove no statistical significant difference in responses of the whole research sample groups opinion on the second factor phrases related to competitive advantage dimensions in sports clubs (costs - quality - flexibility delivery - creation) except for phrases number (4), (8/1), $(5 / 2),(6)$ were statistically significant as value of K2 was greater than the tabular value that ranged between $(* 6.12$ : *17.28)

The total research sample agreement percentage on all phrases of the first dimension (cost) from the second factor reached (68.80: 83.33\%) which is an average percentage.

Also the phrase number (5/1) (5/2) indicating that costs of sports games schools are suitable for internal and external beneficiary according to an agreement between board's members and employees of department of sports activity with percentage between (76.53: 87.50\%) as opinions of the third group, beneficiaries has a lesser percentage (47.50: $50.0 \%$ ) 
These results agree with results of Badria Naily (2012) (8) upon that the organization may have the advantage of the lesser cost if their accumulated costs of activity producing value less than its view to these costs such as possession on the lesser cost advantage, in which controlling costs development factors shall be depended on as good control over those factors compared to competitor provided the organization with the least costs advantage.

According to the second dimension (quality) it is clear that there is an agreement between all the board's members and the sports activity department employees between (68.37: 96.43\%) while the third group opinion, beneficiary about phrases of the same dimension were relatively lesser (48.75: $77.50 \%$ )

Accordingly results of study of Amna Addash (without) confirmed the governance importance in developing competitive performance efficiency under environmental changes and the intense competition between organizations (4)

Hassan Ahmed Elshafie (2010) adds that competitive advantage can be achieved through many integrated activities inside organizations as every activity contributes in certain costs and achieve distinction, the goods added value relates to the opposing activities depending on costs and quality, (15:123)

While the third dimension phrases in the second factor "flexibility", rapid response to changes while may happen in the offered sports services and activities obtained average agreement percentage between opinions of the faculty research groups ranging between (66.67: 71.37\%)

Marwan Mohamed Naguib (2011) States that flexibility represents the basis of achieving eth competitive advantage as high flexibility in services performance may make the organization more able to manufacture components better than distinctive organization one, accordingly it may manufacture new services according to beneficiaries needs and desires which may achieve a competitive advantage (26:72)

While the fourth dimension phrases (delivery) were statistically significant as value of $\mathrm{K} 2$ is greater than the tabular value at (0.05) to prove statistical significant difference between research sample responses as phrases total agreement percentage ranged between $(58.12: 73.8 \%)$

The phrase number (17) related to using new technology in offering activities and services obtained the agreement of the board's members with percentage $(76.79 \%)$ while the second and the third groups opinions were less than this percentage as reached (53.06\%) (51.25\%) respectively.

The phrase number (18/5) related to improving sports clubs services via achieving efficiency and effectiveness of performance, objectives achievement and using substantial and human resources economically obtained higher agreement percentage between the first and the second groups opinion reached $(89.29 \%)(78.57 \%)$ respectively as opinions of the third group "beneficiaries" were lesser as reached $(50.00 \%)$

This was mentioned by Khair Eldin Dada (2012) that organizations survival in market depends on their competitive performance efficiency and effectiveness; this depends on formulating strategies enabling to deal with fierce competition in local and international market, beside strategic analysis of internal environment factors in identifying.

It is clear from table number (7) of correlations coefficients between governance determinants and competitive advantage dimensions in sports clubs that there is a directly proportional relationship between the first dimension "external governance determinants" and all the second factor dimensions in the competitive advantage dimension, and as the value of correlation coefficient between governance external determinants and cost dimension was $(* * 0.627)$ as

In this respect, Ahmed Mounir El Nagar (2007) states that the main determinants of companies governance are represented in internal determinants and rules and basis determining how to take decisions and distributing authorities in the company to the general assembly, board and executive directors which availability from one side and application from the other side may reduce contradiction between the three parties' interests, external determinants indicating the general investment climate in the state. (3:12)

These results agree with what was mentioned by international projects center that governance has a great role in enhancing economy competitive potential as they attract investments and support economic performance and competitive ability on the long term through some methods including. (11).

\section{Conclusions and Recommendations}

\section{First: Conclusion}

Antitrust for some sports services and activities for certain clubs 
Executing laws and rules guaranteeing good administration of sports clubs and their external relationships with other sports competent and non competent organizations.

Sports clubs tries to submit activities and sports services at costs lower than other organizations.

\section{Second: Recommendations:}

Changing the contract administration style in all sports clubs and adopting governance style as a main basis of sports clubs success and achieving a competitive advantage.

Adopting the declaration policy, freedom of expression and questioning in sports clubs

The need to conduct many scientific research in the application of governance in sports clubs

\section{References}

1- Alamgir, M. (2007) Corporate Governance: A Risk Perspective, paper presented to: Coorporate Governance and Reform: Paving the Way to Financial Stability and Development, a conference organized by the Egyptian Banking Institute, Cairo, May 7 - 8 .

2-Abdel Rahman Adnan (2008) Effect of Corporate Governance Effectiveness on the Financial Performance of Companies Listed on PSE, PhD Thesis, Finance Department, Graduate School of Administrative and Financial Studies, and Amman Arab University for Graduate Studies, Jordan.

3-Ahmed Munir Al-Najjar (2007) The Banking Dimension in Corporate Governance, Kuwait Banks Union, Issue 40

4-Ali Al-Salami (2011): Strategic Human Resources Management, Dar Ghraib for Printing and Publishing, Cairo

5-Amdash (None) Governance and its role in improving the competitive performance of economic institutions, Journal of Finance and Markets, Saida University

6-Bader Ayed Al Otaibi (2013) The Impact of Administrative and Social Corruption on Sports Institutions, "European Journal of Sports Science Technology, Second Issue, Kuwait.

7-Badriya Naili (2012) Bank Cards as an Approach to Enhance the Competitive Advantage of Banks, Memeast Memorandum, Kaspersky University.

8-Burberry Sharif Ibrahim (2015) Role of Governance Mechanisms in Reducing Administrative and Financial
Corruption in Sports Institutions, University of Algiers, Issue 3 .

9- Bilal Eid Mohamed (2016): Corporate Governance and its Role in Facing Administrative and Financial Disorders, Publications of the Arab Organization for Administrative Development, League of Arab States, Cairo, Egypt.

10-Boumediene Youssef (2013) : Business Ethics and its Relevance to Good Governance Practices in Contemporary Business Organizations from an Administrative and Islamic Perspective ", Paper presented to the 8th International Conference on: The Role of Governance in Activating the Performance of Institutions and Economies, Faculty of Economic and Commercial Sciences and Management Sciences, Hassiba Ben Bouali University in Chlef, Algeria.

11-Center for International PrivateEnterprise: A Guide to Establishing Corporate Governance in Emerging Markets, www.cipe-arabia.org/pdfhelp.asp

12-Freeland, C. (2007). Basel Committee Guidance on Corporate Governance for Banks, paper presented to: Coorporate Governance and Reform: Paving the Way to Financial Stability and Development, a conference organized by the Egyptian Banking Institute, Cairo, May 7 -8 .

13-Fadl Mohammed Moayad (2015) The Relationship between Corporate Governance and the Quality of Accounting Disclosure in the Light of the Agency's Theory, Publications of the Arab Organization for Administrative Development, League of Arab States, Cairo, Egypt

14-Hammad Abdel Aal Tariq (2007) Corporate Governance, Concepts and Principles, University House, Alexandria, Egypt

15-Hassan Ahmed El Shafei (2010) Logistics in Physical Education and Sports, Dar Al Wafaa Press and Publishing, 1st Floor, Alexandria.

16- Ho,( 2005) Corporate governance and corporate competitiveness: an International analysis, journal of corporate finance, vol .11

17-Hairuddin Bin Daddah (2011) Governance as a Tool for Improving Performance in Small and Medium Enterprises, A Brief Introduction to Completing the Requirements of Master's Degree in Management Science.

18- IIF. Corporate Governance in Poland Greg.R(2003 Institute of International Finance February. 
19-Ibrahim Al-Essawi (2003) Development in a Changing WorldA Study in the Development Concept and Indicators. Cairo: Dar Al Shorouk.

20-Ibrahim Abdel Salam (2009) The Impact of Corporate Governance Practice on Corporate Competitiveness: A Case Study of Jordanian Public Shareholding Companies.

21-Iskander, M. and N. Chamlou. (2002) Corporate Governance: A Framework for Implementation. PP: 119137. Published in: Globalization and Firm Competitiveness in the Middle East and North Africa Region, edited by: S. Fawzy. Washington: World Bank.

22-Jinarat \& Quang, 2003 The Impact of good governance on organizational performance after the Asian crisis in Thailand, MA PHESIS, Management specialties ,Jordan.

23-Kristina Minnick\& Tracy Noga(2009) Do Corporate Governance Characteristics Influence Tax Management?" Bentley University Research Forum, September.

24- Marwan Mohamed Naguib (2010) The Role of Marketing Marketing Mix in Achieving Competitive Advantage, Legal Books House, Cairo

25-Mohiuddin Qutb (2012) Strategic Option and its Impact on Competitive Advantage, Dar Al-Hamed Publishing and Distribution, Amman, Jordan, First Edition.

26-Mohammed Saleh Fromm (2016) The Effect of Corporate Governance on Competitiveness "A Field Study of a Sample of Public Economic Institutions in the State of Skikda" Journal of Business Administration Volume 12 Issue 3, Faculty of Economic Sciences and Management Sciences, Department of Finance. University of Taji Mukhtar Annaba Algeria.

27-Mohamed Hassan Youssef (2007) Determinants and Criteria of Governance, National Investment Bank, Cairo.

28-Mohammed Shalaby Mustafa, Shukri Mohamed Alaa (2013) Role of Social Responsibility in Increasing Competitiveness (Empirical Study on Mobily Saudi Telecom Company), Publications of Arab Organization for Administrative Development, League of Arab States, Egypt.

29-Mohamed Magdy Sayed (2009) A Proposed Concept of the Administrative Policies of the Referees Committees of the Egyptian Handball Federation in light of the
Principles of Governance, Unpublished Master Thesis, Assiut University.

30-Mustafa Mahmoud Abu Bakr (2005) : Human Resources Management, "Introduction to Achieving Competitive Advantage", University House, Alexandria

31-Manwar Haddad (2008) Manwar Haddad (2008): The Role of Corporate Governance in Economic Development "The First Scientific Conference" on Corporate Governance and its Role in Economic Reform during the period October 15-16, Damascus University.

32-National Bank of Egypt (2003) The Practice of Corporate Governance Authorities: Corporate Governance. Economic Bulletin, No. 2, vol

33-Nasser, Al Nuaimi, Khalis Yusuf

Abdul Wahid (2013) The Role of Corporate Governance in Developing the Investment Environment and Attracting Foreign Investment in the Kurdistan Region of Iraq, Nooroz University Journal, No (1), Dohuk, Iraq

34-Nabil Morsi Khalil (2009) Competitive Advantage in Business, Alexandria Center for Book Egypt

35-Rashed Ibrahim Al-Naimi (2015) The Effect of the Application of Governance in Sports Institutions on the Achievements of Olympic Sports in the UAE from the Point of View of Decision-makers, Faculty of Humanities and Social Sciences, United Arab Emirates University

36-Reham Amin Hamza (2015) Requirements for the Application of Governance in Sports Clubs, Research published at the 16th International Scientific Conference, School Sports and Challenges of Change in the Arab World (6-8) November.

37-Shuli Ingrid, 2011 Earnings management and the quality of the financial reporting, Economies and Business, vol.8, Issue 2.

38-Terres Udisho (2011) Mathematical Governance Principles and Practice, Iraqi Olympic Academy, Baghdad.

39- http://wormac.com/define-of-governance-and-origins/ 40- http://mawdoo3.com/-

41- https://www.bayt.com/en/specialties/q/9876-

42- http://www.alweeam.com.sa/ 